\title{
TRADISI, SUNNAH \& BID'AH: Analisa Barzanji Dalam Perspektif Cultural Studies
}

\author{
Wasisto Raharjo Jati \\ Jurusan Politik dan Pemerintahan FISIPOL UGM \\ Jl. Teknika Utara, Pogung, Yogyakarta. Telp. 0274552212 \\ email: wasisto.raharjo.jati@mail.ugm.ac.id
}

\begin{abstract}
The discussion about barzanji is not only in the theological debate, but also in the cultural debate. The paradigm of sunnah and bid'ah that has contained the study of Islamic theology has been developed in to cultural studies that puts them in a reciprocal relationship. This study aimed to analyze barzanji in the critical culture debate which emerged a new perspective on the dichotomy of sunnah and bid'ah even becomed more dynamic in analyzing culture.

Diskusi tentang barzanji tidak hanya terjadi dalam perdebatan teologis saja, akan tetapi juga dalam perdebatan budaya. paradigma tentang sunnah dan bid'ah yang selama ini terdapat dalam kajian teologi Islam berkembang dalam kajian budaya yang menempatkan keduanya dalam relasi timbal balik. Studi ini menggunakan analisa cultural studies untuk mengkaji barzanji dalam perdebatan kritis budaya khususnya, yang memberikan cara pandang baru terhadap dikotomi sunnah dan bid'ah menjadi lebih dinamis dalam menganalisis budaya.
\end{abstract}

Key words: barzanji, sunnah, bid'ah, cultural studies.

\section{Pendahuluan}

Peringatan Maulid Nabi Muhammad SAW setiap tanggal 12 Rabi'ul Awal senantiasa dirayakan dalam nuansa tradisi budaya lokal yang kental oleh umat Islam di Indonesia. Perayaan hari lahir Nabi atau umat Islam Indonesia menyebutnya sebagai "Mauludan" dirayakan secara beraneka ragam misalnya saja di Banten dan Cirebon, ribuan umat Islam mendatangi kompleks Masjid 
Agung Banten maupun makam Sunan Gunung Jati melakukan ziarah makam wali dan sultan sekaligus mengikuti prosesi pemandian pusaka-pusaka dimana setelah itu air cucian pusaka tersebut lantas menjadi bahan rebutan karena dipercaya airnya mengandung barokah. Selain itu, bagi daerah yang merupakan basis kerajaan Islam di Jawa seperti halnya Surakarta maupun Yogyakarta, perayaan maulid dikenal dengan istilah Sekaten yang berasal dari kata syahadatain yaitu dua kalimat syahadat. Prosesi Sekaten sendiri diawali dengan miyos gongso yakni dikeluarkannya kedua perangkat gamelan Kyai Nogo Wilogo dan Kyai Guntur Madu dari tempat penyimpanannya di Bangsal Sri Manganti ke Bangsal Ponconiti terletak di Kemandungan Utara (Keben) pada tanggal 5 Rabi'ul Awal yang kemudian dibunyikan secara serentak selama 7 hari berturut-turut hingga pada puncak Sekaten pada 12 Rabi'ul Awal. Pada umumnya, masyarakat Yogyakarta dan sekitarnya berkeyakinan bahwa dengan turut berpartisipasi merayakan hari kelahiran Nabi Muhammad SAW ini akan mendapat imbalan pahala dari Allah SWT dengan dianugerahi awet muda maupun barokah lainnya. tradisi budaya lokal mauludan ini juga tersaji dalam Grebeg Mulud di Demak, Panjang Jimat di Kasultanan Cirebon, Mandi Barokah di Cikelet Garut, dan sebagainya (Nizaruddin, 2007: 5).

Diantara berbagai tradisi menyambut Maulid Nabi tersebut yang ada dalam kultur tradisi budaya Islam lokal Indonesia, salah satu tradisi yang menarik dan wajib dilaksanakan oleh kalangan umat muslim adalah pembacaan Kitab Barzanji (orang Jawa secara lisan menyebutnya sebagai 'Berjanji' atau 'Berjanjen'). Barzanji atau sholawat (barzanjen) adalah bentuk kesenian yang bernafaskan Islam atau sebagai sarana dakwah Islam dengan Kitab Barzanji sebagai sumbernya (Paisun, 2010: 24). Kitab Barzanji sendiri adalah karya tulis dari Syekh Ja'far Ibnu Hasan Ibnu Abdul Karim Ibnu Muhammad al Barzanji yang berisi tentang prosa dan sajak yang bertutur tentang biografi Nabi Muhammad SAW, mencakup nasab-nya (silsilah), kehidupannya dari masa kanak-kanak hingga menjadi rasul. Selain itu diceritakan pula berbagai nilai suri tauladan beliau yang patut untuk dicontoh oleh generasi umat Islam Indonesia pada khususnya. Adapun dalam pemahaman lainnya, Barzanji merupakan suatu doa-doa, puji-pujian dan penceritaan riwayat Nabi Muhammad SAW yang biasa dilantunkan dengan irama atau nada. Tradisi budaya Islam ini dapat dikategorikan sebagai kelompok seni pertunjukan yang terdiri dari vokal, musik, dan tanpa tari atau gerakan badan. Kelompok dalam kesenian ini cukup banyak lebih dari 20 orang bisa laki-laki ataupun perempuan muda atau dewasa. Kesenian pembacaan barzanji ini pada umumnya 
ditampilkan pada malam hari dengan posisi berdiri. Bisa dikatakan tradisi barzanji ini mirip dengan seni musik acapella lainnya seperti nasyid yang kini tengah populer, namun berbeda dengan nasyid kini sudah merangkul musik modern sebagai saran dakwah. Tradisi seni barzanji sendiri sangat terikat dengan kultur mengingat barzanji sendiri merupakan syair puji-pujian kepada Nabi Muhammad SAW.

Namun demikian, pembacaan barzanji sebagai tradisi perayaan maulid Nabi hingga kini masih dipertanyakan keabsahannya. Hal ini dikarenakan hukum perayaan maulid itu sendiri masih menjadi perdebatan. Sebagian ulama berpendapat bahwa tradisi barzanji adalah bid'ah, karena dari sisi syar'i tidak ada dasarnya. Dari sisi teologis, para ulama tersebut menilai barzanji mengarah pada pengkultusan Nabi Muhammad SAW yang sejatinya dilarang dalam ajaran agama. Akan tetapi, ada pula sebagian ulama yang berpendapat bahwa pembacaan barzanji dalam rangka peringatan maulid Nabi adalah sunnah karena hal itu akan semakin meningkatkan dan mengamalkan ajaran Islam sebagaimana yang diwasiatkan oleh Nabi Muhammad SAW sendiri. Perdebatan tersebut kemudian berimplikasi meluas pada pemaknaan tradisi barzanji sendiri apakah masih relevan dilakukan sebagai penghargaan terhadap Nabi Muhammad yang membawa Islam sebagai rahmatal lil alamin ataukah barzanji berimplikasi pada pengkultusan Nabi dimaknai sang penyelamat umat manusia seperti halnya ajaran messianik dalam teologi Nasrani menilai Nabi Isa AS sebagai al Masih yang tentunya berimplikasi terbentuknya sikap syirik kepada umat muslimin Indonesia. Maka, tulisan dalam makalah ini mengkaji polemik yang berkembang dalam tradisi barzanji sendiri dalam kerangka perdebatan kajian budaya dalam bingkai cultural studies terutama dalam perspektif kajian budaya dalam menilai sunnah ataukah bid'ah khususnya dikaitkan dengan implementasi barzanji di kalangan umat muslimin Indonesia. Adapun pembahasan dalam tulisan ini akan dibagi dalam berbagai sub-bab. Pertama, menceritakan secara ringkas perkembangan sejarah tradisi barzanji. Kedua, memaparkan masuknya tradisi barzanji dalam Islam lokal di Indonesia. Ketiga, menganalisis perdebatan seputar analisis barzanji tersebut dalam analisa kritis. Keempat, kesimpulan dari tulisan makalah ini.

\section{Sejarah Tradisi Seni Barzanji}

Tradisi barzanji yang esensinya menghaturkan pujian kepada Nabi Muhammad SAW adalah tradisi yang usianya setua Islam itu sendiri karena tradisi ini telah ada semasa beliau masih hidup. Tradisi ini diperkenalkan 
oleh tiga penyair resmi Rasulullah SAW, yaitu Hasan Ibnu Tsabit, Abdullah Ibnu Rawahah, dan Ka'ab Ibnu Malik. Diceritakan dalam riwayat Ibrahim al Bajuri dalam Hasyiyat al Bajuri 'ala Matn Qasidah al Burdah bahwa tradisi pujian kepada Rasulullah ini merupakan tradisi yang perlu didorong dan dilestarikan oleh umatnya agar senantiasa patuh pada Allah dan Rasul-Nya (al Bajuri, 1947: 22).

Hal tersebut terindikasi ketika Nabi memuji Ka'ab Ibnu Zubair yang menggubah qasidah pujian kepadanya. Setelah mendengarkan pujian yang disampaikan oleh Ka'ab sangat terkesan, sampai-sampai Nabi melepas burdahnya dan dikenakan ke tubuh Ka'ab sebagai hadiah sekaligus ungkapan persetujuan (Supani, 2007: 82). Qasidah pujian yang digarap oleh tiga penyair Rasulullah dan Ka'ab kemudian menjadi acuan bagi para penyair muslim, ketika berkreasi menciptakan pujian, baik dalam bentuk sya' ir (puisi) maupun nathr (prosa), sebagaimana tampak dalam tiga Kitab Barzanji, Burdah, dan Syaraf al Anam yang beredar sampai sekarang. Produktivitas karya pujian mereka kepada Nabi melahirkan jenis pujian khas, dan dengan karakter yang spesifik, yang dalam kajian sastra Arab dikenal dengan istilah al Mada'ih al Nabawiyah.

Tradisi pujian kepada Nabi Muhammad SAW ini kemudian dilanggengkan oleh berbagai kekhalifahan Islam Syi'ah seperti Dinasti Fatimiyah di Mesir yang wajib dinyayikan oleh segenap oleh masyarakatnya manakala perayaan Maulid Nabi tiba pada bulan Rabi'ul Awal. Bagi khalifah dinasti ini, tradisi pujian sendiri diresmikan sebagai tradisi negara maupun sebagai legitimasi politis bahwa dinasti inilah yang merupakan kekhalifahan Islam berdasar garis keturunan Nabi. Umat Islam Sunni juga merayakan maulid Nabi dengan menghaturkan puji-pujian di berbagai daerah seperti Bukhara, Samarkand, Mosul, Mekkah, maupun Damaskus, namun tetap saja dilakukan secara sembunyi agar tidak dituduh bid'ah. Selepas Dinasti Fatimiyah tutup usia, tradisi pujian ini kemudian diteruskan oleh Sultan Salahuddin Yusuf al Ayyubi (Saladin) dari Dinasti Bani Ayyub (1174-1193 M atau 570-590 H). Menurut Sultan Salahuddin, tradisi menyanyikan pujian kepada Rasulullah SAW dapat mempertebal keimanan dan ketakwaan kepada rasulnya sekaligus juga menambah semangat juang meliputi membangkitkan semangat jihad (perjuangan) dan ittihad (persatuan) dalam Perang Salib III melawan Pasukan Nasrani dari Eropa yang berupaya menduduki Yerusalem. Saladin pula yang menghidupkan tradisi merayakan Maulid Nabi pertama kali pada $184(580 \mathrm{H})$ adalah menyelenggarakan sayembara penulisan riwayat Nabi beserta puji-pujian bagi Nabi dengan bahasa yang seindah mungkin. Seluruh ulama dan sastrawan 
diundang untuk mengikuti kompetisi tersebut. Pemenang yang menjadi juara pertama adalah Syaikh Ja ` far al Barzanji dengan hasil karyanya yang dikenal Iqd al Jawahir (kalung permata) atau familiar dengan sebutan Kitab Barzanji. Syaikh Ja'far al Barzanji juga seorang Qodhi (hakim) dari madzhab Maliki yang bermukim di Madinah, merupakan salah seorang keturunan (buyut) dari cendekiawan besar Muhammad bin Abdul Rasul bin Abdul Sayyid al Alwi al Husain al Musawi al Saharzuri al Barzanji (1040-1103 H atau 1630-1691 M), Mufti Agung dari madzhab Syafi'i di Madinah. Sang Mufti (pemberi fatwa) berasal dari Shaharzur, kota kaum Kurdi di Irak, lalu mengembara ke berbagai negeri sebelum bermukim di Kota Sang Nabi. Di sana beliau telah belajar dari ulama-ulama terkenal, diantaranya Syaikh Athaallah Ibnu Ahmad al Azhari, Syaikh Abdul Wahab at Thanthowi al Ahmadi, Syaikh Ahmad al Asybuli. Beliau juga telah diijazahkan oleh sebahagian ulama', antaranya : Syaikh Muhammad at Thoyib al Fasi, Sayid Muhammad at Thobari, Syaikh Muhammad Ibnu Hasan Al A'jimi, Sayid Musthofa al Bakri, Syaikh Abdullah as Syubrawi al Misri (Albiruny, 2012: 2). Syaikh Ja'far al Barzanji, selain dipandang sebagai Mufti, beliau juga menjadi khatib di Masjid Nabawi dan mengajar di dalam masjid yang mulia tersebut. Beliau terkenal bukan saja karena ilmu, akhlak dan taqwanya, tapi juga dengan kekeramatan dan kemakbulan doanya. Penduduk Madinah sering meminta beliau berdo'a untuk hujan pada musimmusim kemarau.

Dalam kitab tersebut, riwayat Rasulullah disyairkan dengan bahasa yang indah dalam bentuk puisi, prosa dan kasidah yang sangat menarik. Secara garis besar, paparan al Barzanji dapat diringkas sebagai berikut: (1) Silsilah Nabi adalah: Muhammad bin Abdullah bin Abdul Muttalib bin Hasyim bin Abdul Manaf bin Qusay bin Kitab bin Murrah bin Fihr bin Malik bin Nadar bin Nizar bin Maiad bin Adnan. (2) Pada masa kecil banyak kelihatan luar biasa pada dirinya. (3) Berniaga ke Syam ikut pamannya ketika masih berusia 12 tahun. (4) Menikah dengan Khadijah pada usia 25 tahun. (5) Diangkat menjadi Rasul pada usia 40 tahun, dan mulai menyiarkan agama sejak saat itu hingga umur 62 tahun. Rasulullah meninggal di Madinah setelah dakwahnya dianggap telah sempurna oleh Allah SWT.

Dalam narasi kitab tersebut, keagungan akhlak Nabi Muhammad tergambarkan dalam setiap tindakannya sehari-hari. Sekitar umur tiga puluh lima tahun, beliau mampu mendamaikan beberapa kabilah dalam hal peletakan batu Hajar Aswad di Ka'bah. Di tengah masing-masing kabilah yang bersitegang mengaku dirinya yang berhak meletakkan Hajar Aswad, Rasulullah tampil 
justru tidak mengutamakan dirinya sendiri, melainkan bersikap akomodatif dengan meminta kepada setiap kabilah untuk memegang setiap ujung sorban yang ia letakkan di atasnya Hajar Aswad. Keempat perwakilan kabilah itu pun lalu mengangkat sorban berisi Hajar Aswad, dan Rasulullah kemudian mengambilnya lalu meletakkannya di Ka'bah. Kisah lainnya seperti pada suatu pengajian seorang sahabat datang terlambat, lalu ia tidak mendapati ruang kosong untuk duduk. Bahkan, ia minta kepada sahabat yang lain untuk menggeser tempat duduknya, namun tak ada satu pun yang mau. Di tengah kebingungannya, Rasulullah SAW memanggil sahabat tersebut dan memintanya duduk di sampingnya. Namun tidak hanya itu, Rasul kemudian melipat sorbannya lalu memberikannya pada sahabat tersebut untuk dijadikan alas tempat duduk. Melihat keagungan akhlak Nabi tersebut, sahabat itu pun langsung mencium sorban Nabi sebagai tanda baktinya kepadanya (Munawaroh, 2007: 35).

\section{Tradisi Barzanji dalam Budaya Islam Lokal Indonesia}

Masuknya tradisi barzanji ke Indonesia tidak terlepas dari pengaruh orang-orang Persia yang pernah tinggal di Gujarat yang berpaham Syiah yang pertama kali menyebarkan Islam di Indonesia. Pendapat ilmiah yang lain mengatakan bahwa tradisi barzanji sendiri dibawa oleh ulama bermahzab Syafii terutama Syekh Maulana Malik Ibrahim yang dikenal gurunya Wali Songo berasal kawasan Hadramaut (Yaman) dalam menyebarkan Islam di daerah pesisir Sumatera Timur maupun Pantai Utara Jawa yang dikenal amat toleran dan moderat dalam berdakwah dengan mengasimilasikannya dengan tradisi maupun kultur lokal. Seni barzanji kemudian turut menginsipirasi Sunan Kalijaga untuk menciptakan lagu li-ilir maupun tombo ati yang sangat familiar di kalangan pesantren dalam melakukan dakwahnya di kawasan pedalaman Jawa (Suparjo, 2008: 180).

Oleh karena itulah, tradisi barzanji ini kemudian berkembang pesat di kalangan pesantren-pesantren yang tersebar di Jawa Tengah maupun Jawa Timur. Nahdlatul Ulama (NU) yang notabene dianggap sebagai pesantren besar dianggap sebagai organisasi pelestari tradisi ini. Hal ini dikarenakan pengaruh Syi'ah di NU sangat besar dan mendalam. Kebiasaan membaca barzanji atau Diba'i yang menjadi ciri khas masyarakat NU berasal dari tradisi Syi'ah. Makanya kemudian Kiai Abdurrahman Wahid atau Gus Dur pernah menyebut bahwa salah satu pengaruh tradisi Syiah dalam corak keislaman di Indonesia adalah praktik nyanyian (biasa disebut juga pujian) menjelang 
salat yang biasa dipraktikkan di kalangan warga nahdliyyin (NU). Nyanyian itu berisi pujian untuk "ahl albait" atau keluarga Nabi, istilah yang sangat populer di kalangan Syiah maupun nahdliyyin. Bunyi nyanyian itu ialah: Li khamsatun uthfi biha, harra al Waba' al Hathimah, al Mushthafa wa al Murtadla, wa Ibnuahuma wa al Fathimah. Terjemahannya: Aku memiliki lima "jimat" untuk memadamkan epidemi yang mengancam; mereka adalah al Musthafa (yakni Nabi Muhammad), al Murtadla (yakni Ali Ibnu Abi Talib, menantu dan sepupu Nabi), kedua putra Ali (yakni Hasan dan Husein), dan Fatimah (istri Ali). Gus Dur menyebut gejala ini sebagai "Syiah kultural" atau pengaruh Syiah dari segi budaya, bukan dari segi akidah.

Tradisi pembacaan barzanji kepada Rasulullah SAW sebagaimana yang dilakukan oleh kalangan pesantren biasanya dilandaskan kepada pendapat para fuqaha dari mazhab Syafi'i. Ibnu Hajar alAtsqalani, misalnya, menyatakan bahwa tradisi seperti itu menyimpan makna kebajikan (Solikhin, 2011: 75). AlSuyuthi juga menunjukkan sikap toleran terhadap produk budaya yang dihasilkan oleh tradisi mengagungkan kelahiran Rasulullah SAW. Sikap kedua fuqaha tadi juga disepakati oleh fuqaha Syafi'I yang lain, seperti Ibnu Hajar alHaytami dan Abu Shamah. Bagi kedua ulama terakhir ini, peringatan Maulid menjadi satu perbuatan (baru) yang paling terpuji (wa min ahsani ma ubtudi-a), jika disertai dengan amal ihsan kemasyarakatan, seperti sadaqah, infaq, serta kegiatan lain yang bernilai ibadah. Mereka percaya bahwa dengan menyanyikan barzanji pada saat perayaan Maulid Nabi akan memperoleh syafaatnya pada hari kiamat kelak, dalam penggalan hadits berikut ini:

"Siapa yang menghormati hari lahirku, maka dia akan memperoleh syafaatku pada hari akhir kelak".

Maka adanya pedoman hadits inilah yang kemudian barzanji kemudian marak dilakukan oleh kalangan masyarakat NU pada khususnya (Syadzii, 2010: 43). Adapun tradisi barzanji kini mulai dilakukan di berbagai kesempatan tidak hanya dalam kegiatan pesantren semata, sebagai sebuah pengharapan untuk pencapaian sesuatu yang lebih baik, misalnya pada saat kelahiran bayi, mencukur rambut bayi (aqiqah), acara khitanan, pernikahan, dan upacara lainnya. Dalam kegiatan keagamaan di masjid-masjid perkampungan, biasanya jamaah duduk bersimpuh melingkar. Lalu seseorang membacakan barzanji, yang pada bagian tertentu disahuti oleh jemaah lainnya secara bersamaan. Di tengah lingkaran terdapat nasi tumpeng dan makanan kecil lainnya yang dibuat warga setempat secara gotong-royong. Terdapat adat sebagian masyarakat, dimana pembacaan barzanji juga dilakukan bersamaan dengan dipindah- 
pindahkannya bayi yang baru dicukur selama satu putaran dalam lingkaran. Sementara baju atau kain orang-orang yang sudah memegang bayi tersebut, kemudian diberi semprotan atau tetesan minyak wangi atau olesan bedak, barzanji juga sering dibaca di berbagai acara, seperti menjelang pernikahan, pindah rumah baru, beli kendaraan baru, dan di berbagai kesempatan. Dalam kesempatan lainnya, barzanji juga dilakukan dalam rangka guna untuk meminta izin dan memulai pelaksanaan sedekah bumi. Setelah sampai disana, tetua adat kemudian duduk di dekat makam bersamaan dengan dihidangkan berbagai macam jenis makanan khas desa, uang serta bunga sebagai pranata upacara. Hal ini lazim dilakukan oleh masyarakat Jawa dalam upacara sadranan pada bulan Sya'ban dimana barzanji dilakukan untuk mendoakan ruh para leluhur yang telah meninggal.

\section{Polemik Barzanji: Tradisi, Sunnah, dan Bid'ah}

Kajian kritis terhadap barzanji di Indonesia bisa dikatakan masih belum menyentuh pada tataran normatif, namun belum menyentuh pada kajian kritis terutama perdebatan tradisi barzanji sebagai sunnah ataukah bid'ah. Penelitian terhadap masalah tersebut menjadi penting karena selama ini belum ada suatu riset yang khusus membahas masalah itu. Penelitian terdahulu tentang tradisi barzanji seperti halnya Ahmad Ta'rifin (2010) dalam Tafsir Budaya atas Tradisi barzanji dan Manakib dan Muhammad Anas (2010) dalam Nilai Pendidikan Akhlak dalam Kitab Barzanji, keduanya menyoroti barzanji sebagai media dakwah sekaligus sarana pendidikan akhlak bagi generasi muda agar senantiasa menjadikan Nabi Muhammad SAW sebagai uswatun hasanah, namun Muhammad Anas condong kepada kajian linguistik pada sastra barzanji menemukan bahwa terdapat nilai dan norma yang dapat diteladani dari sosok Nabi Muhammad SAW dalam membentuk moral dan etika murid di sekolah. Kholid Mawardi (2009) dalam Shalawatan: Pembelajaran Akhlak Kalangan Tradisionalis mempunyai lokus studi sama dengan Ahmad Ta'rifin yang menyoroti tentang barzanji sebagai sarana pendidikan akhlak, namun juga sebagai politik perlawanan bagi kalangan tradisionalis bahwa barzanji sebagai pembelajaran pendidikan akhlak bagi santri merupakan cara resistensi terhadap pendidikan akhlak di kalangan modernis yang mengakulturasikan nilai-nilai Barat terhadap sistem pendidikan (tarbiyah) Islam. Namun demikian, studi mengenai tradisi barzanji tidak hanya dalam dalam bingkai pendidikan akhlak saja. Dalam kajian yang dilakukan oleh M. Junnaid (2008) dalam Tradisi Barzanji Sya'ban Masyarakat Bugis Wajo di Pantai Tanjung Jabung Timur 
maupun Sri Sukatmi (2005) dalam Perkembangan Seni Barzanji di Pondok Pesantren Roudlotul Muta'allimin mempresentasikan adanya survivalitas dari tradisi barzanji untuk mempertahankan tradisi di tengah gempuran modernisasi dan globalisasi. Bahkan Sri Sukatmi dalam kajiannya tersebut meneropong adanya kebutuhan berkesenian bagi masyarakat di sekitar Pondok Pesantren Roudlotul Muta'allimin terhadap perkembangan tradisi barzanji sebagai sarana hiburan dan edukasi bagi masyarakat. Pada akhirnya kemudian, barzanji atau dalam bahasa masyarakat sebagai berjanjen ini menjadi ajang kompetisi suara merdu dalam pembacaan kitab barzanji tersebut.

Membahas tradisi barzanji dalam kerangka perdebatan sunnah ataukah bid'ah membawa pada konestasi antara kalangan modernis dan tradisionalis yang kemudian membawa implikasi secara general mengenai keabsahan sah dan tidaknya peringatan maulid dilakukan di Indonesia. Sekiranya hal itu masih menjadi perdebatan hingga kini dalam kalangan umat muslimin Indonesia. Meskipun barzanji sebagai bagian dari tradisi diakui oleh pemerintah, namun sebagian ada yang menilai bahwa tradisi pembacaan kitab barzanji tersebut tidak diatur dalam al Quran dan Hadits secara eksplisit sehingga dianggap bid'ah. Pemahaman bid'ah yang disematkan kepada ajaran barzanji sendiri ternyata juga terpecah dalam dua jenis yakni bid'ah mazmumah yang membangun argumentasinya melalui pendekatan normatif tekstual bahwa yang tidak ada ajarannya dalam al Quran dan Hadits adalah menyesatkan. Pendapat kedua adalah bid'ah mahmudah yang menilai bahwa pembacaan barzanji memang tidak ada rujukannya dalam al Quran dan Hadits, namun secara ajarannya tidak bertentangan dalam Islamnya karena mengajak kepada kebajikan yakni meningkatkan iman dan takwa kepada Allah SWT. Mendudukkan barzanji dalam dikotomi sunnah ataukah bid'ah membawa kita kepada pemahaman tentang konstruksi pengetahuan yang berada di balik belakang "vonis" tersebut. Konstruksi tersebut dapat dapat berupa kajian ideologi maupun teologi yang mendasarinya adanya konstruksi tersebut. Barzanji yang sejatinya sebagai sebuah produk sastra dalam budaya Islam sebenarnya tidak terlepas dari hal tersebut. Oleh karena itu, penting untuk disimak dasar dari vonis tersebut.

\section{Barzanji dalam kerangka Cultural Studies}

Aplikasi dari cultural studies dalam menganalisis tradisi barzanji ini bisa dipahami dalam dua ranah yang berbeda yakni sebagai konsep dan teori. Sebagai konsep, cultural studies digunakan untuk melihat bekerjanya kekuasaan dalam produk budaya dan kebudayaan. Budaya kemudian berkembang sebagai 
politik identitas bagi entitas tertentu yang ingin menyimbolkan kuasanya dalam sebuah produk budaya (Hall, 2006: 58). Artinya setiap individu dapat membincangkan barzanji dalam ruang publik kepada entitas tertentu secara tidak langsung sudah menunjukkan domain dari kuasa budaya tersebut. Sebagai teori, cultural studies terutama dalam kajian teori kritis menyebutkan bahwa ambivalensi tertentu tentang sumber utama atau dasar dari dominasi kuasa atas produk budaya yang dijadikan sebagai simbolisasinya. Artinya bahwa ambivalensi tersebut kemudian melahirkan adanya berbagai bentuk kritikan dan skeptisme bagi entitas lain yang berusaha melawan dominasi budaya tersebut dengan semangat pembebasan bahwa produk budaya adalah netral dari kuasa karena esensinya sebagai media penyampai nilai-nilai luhur dan hiburan bagi masyarakat. Adapun konstruksi antara sunnah dan bid'ah dalam menilai tradisi barzanji tersebut sebenarnya tidak terlepas dari dua pemahaman tersebut. Harus diakui bahwa dikotomi tersebut pada akhirnya akan meruncing pada perdebatan konsep teologis dan syar'i yang selama ini menjadi dasar dari vonis tersebut. Namun kita bisa menelisik dasar teologis dan syar'i tersebut melalui konstruksi cultural studies ini. Adapun dalam bahasa kajian budaya, sunnah maupun bid'ah lebih disebabkan adanya kontestasi budaya yang saling kait-mengkait antar dua entitas yang berbeda. Konstruksi sunnah sendiri sebenarnya merupakan penegasan bahwa apa yang disunnahkan sebenarnya telah diatur dalam bingkai kuasa dari sebuah produk kebudayaan tertentu yang kemudian berkembang dalm konsep teologis, ideologi, dan lain sebagainya. Sementara konstruksi bid'ah sendiri merupakan bentuk penegasian terhadap kuasa tersebut bahwa budaya haruslah netral dari kuasa. Sebuah produk budaya haruslah fokus kepada pengamalan nilai karsa, cipta, dan esetetika sebagai seni dan bukan terkooptasi oleh dunia kekuasaan.

\section{Barzanji dalam Domain Budaya Sunnah}

Tradisi barzanji bisa dikatakan sebagai ibadah yang sifatnya sunnah dalam kacamata cultural studies karena terdapat berbagai alasan yang melatarbelakanginya, misalnya saja. (1) meningkatkan semangat kecintaan dan pengamalan nilai kesalehan kepada Nabi Muhammad SAW sebagai uswatun hasanah yang patut dicontoh oleh masyarakat masa kini. Dalam hal ini, terdapat transfer nilainilai luhur yang bisa diambil dari sosok Nabi sendiri untuk bisa diamalkan dalam kehidupan sehari-hari. (2) merekatkan ukhuwah islamiyah diantara umat muslim karena pergelaran bazanji sendiri selalu melibatkan banyak orang dan massa melihatnya juga banyak sehingga disamping mendapatkan nilai 
edukasi dari pembacaan tradisi barzanji serta meningkatkan interaksi antar sesama masyarakat. (3) meningkatkan amalan ibadah tertentu bagi individu yang senantiasa membaca barzanji di setiap waktu senggangnya karena barzanji secara langsung menuntun seseorang untuk mengamalkan salah satu poin dalam rukun iman yakni kepada Rasul dan Nabi Allah (Ta'rifin, 2010: 2).

Secara garis besar, barzanji sebagai ritus budaya memang berkembang pesat di kalangan pesantren, kalangan nahdlyyin, kalangan Islam tradisionalis, maupun kalangan Islam kejawen. Hal ini dikarenakan tradisi barzanji sebagaimana dengan tradisi maulud lainnya secara umum merupakan bentuk dari ajaran syiah kultural yakni menghormati dan mengenang peran dan jasa Nabi Muhammad SAW, shahabat, dan keturunannya yang berjasa menyebarkan Islam sebagai agama rahmatal lil alamin kepada semesta dalam bentuk ekspresi kebudayaan maupun produk budaya. Dalam sebuah hadits disebutkan bahwa pembacaan barzanji sebagai wujud cinta kepada Rasul merupakan kewajiban bagi semua umat Islam. Sebagaimana tersebut dalam sebuah hadits Nabi: "Tidak sempurna iman seseorang sehingga aku menjadi orang yang paling dicintainya dari pada anaknya, orang tuanya dan manusia semuanya" (HR. Bukhari). Berikut ini merupakan lirik barzanji yang mencerminkan rasa kecintaan yang mendalam kepada Nabi Muhammad SAW.

Contoh Lirik Barzanji yang dianggap sunnah

"Seperti cantikmu tak pernah kupandang

Aduhai wajah ceria

Engkau matahari, engkau purnama

Engkau cahaya di atas cahaya

Engkau permata tak terkira

Engkau lampu di setiap hati

Aduhai kekasih, duhai Muhammad

Aduhai pengantin rupawan

Aduhai yang kokoh, yang terpuji

Aduhai imam dua kiblat"

(Najieh, 1987).

Makna yang ingin disampaikan dalam syair tersebut adalah betapa menunjukkan keagungan Nabi Muhammad SAW yang tidak bisa tertandingi oleh makhluk apapun di dunia karena Rasul sebagai kekasih Allah SWT berkat ketakwaan maupun keimanannya yang begitu tinggi sehingga derajatnya ditinggikan oleh Allah SWT. Syair ini kemudian acap kali dinyayikan dalam berbagai kegiatan keagamaan di pesantren maupun masyarakat pedesaan 
lainnya. Yang kemudian diakhiri dengan bacaan shalawat dan pujian kepada Rasulullah bergema saat kita membacakan barzanji di acara peringatan maulid Nabi Mauhammad SAW, Ya Nabi salâm 'alaika, Ya Rasûl salâm 'alaika, Ya Habîb salâm 'alaika, ShalawatulLâh 'alaika... / Wahai Nabi salam untukmu, Wahai Rasul salam untukmu, Wahai Kekasih salam untukmu, Shalawat Allah kepadamu.

Konstruksi sunnah dalam barzanji adalah baik dan sangat dianjurkan karena hal itu tidak bertentangan sama sekali dengan nilai-nilai ajaran al Quran dan Hadits secara literer. Pembacaan tradisi barzanji yang selama ini dilakukan baik dalam bulan Maulud, maupun event-event tertentu dengan membaca tiga sumber utama al Barzanji, al Diba' atau Syaraf al Anam diorientasikan pada aspek dakwah dan sosial dengan tujuan menggairahkan kehidupan beragama dalam keluarga, masyarakat, dan meningkatkan penghayatan dan pengamalan ajaran agama. Kegiatannya bervariasi sesuai kebutuhan dan orientasi lembaga pelaksananya, antara lain ceramah, lomba, diskusi/seminar, khitanan massal, pengobatan gratis, pasar murah (bazar), dan berkunjung ke panti asuhan. Maka sebenarnya tradisi barzanji itu adalah sunnah karena mengajak pada peningkatan aspek-aspek kehidupan sosial bagi masyarakat. Meskipun barzanji secara tidak langsung menjadi produk budaya esklusif pada empat golongan tersebut sebagai identitas, namun pada praktiknya barzanji sendiri sebenarnya adalah inklusif karena terdapat proses deliberasi budaya yang berlangsung di sana.

Dimensi sunnah dalam kacamata budaya pada barzanji tidak terlihat dalam dimensi sosial saja, namun juga berfungsi sebagai ajang peningkatan religiositas yang mendorong adanya sikap kesalehan sosial yang dicontohkan kepada Nabi untuk ditiru umatnya tentang Beraneka lagu-lagu lembut dan berwarna seperti dalam pembacaan barzanji berfungsi sebagai sarana pendidikan akhlak. Kondisi semacam ini mutlak bagi kalangan pesantren dan nahdliyyin dimana barzanji bersama shalawatan, wirid, dan lain sebagainya merupakan upaya melestarikan tradisi budaya yang berkembang semasa Nabi Muhammad SAW hidup untuk diteruskan hingga sekarang ini (Muzakka, 2003: 12). Hal inilah yang menjadikan alasan barzanji hidup dan berkembang di kalangan Islam tradisionalis karena semata-mata hal itu merupakan bentuk sunnah bahwa melestarikan tradisi Nabi adalah baik disesuaikan dengan ajaran al Quran dan Hadits sehingga tidaklah relevan kalau menyebut barzanji itu menyimpang karena itu sudah ada sejak zaman Nabi dan diperbolehkan oleh Nabi sendiri sebagai bentuk ekspresi budaya untuk mencintai Allah dan Rasul-Nya. Maka dari itulah, upacara pembacaan barzanji merupakan ritus religius dan dimaksudkan 
untuk ibadah yakni taqarrub ilallah yakni menjalin hubungan dekat dengan Allah SWT untuk mendapatkan ridha-Nya. Barzanji sebagai produk budaya kuasa kalangan tradisionalis lebih mengajak pada pengamalan ajaran Islam melalui dimensi riil kehidupan sosialnya yang tidak hanya terpaku pada ajaran leksikal al Quran dan Hadits saja yang bagi sebagian umat sangatlah kaku dan konservatif sehingga melalui tradisi barzanji maupun tradisi lainnya yang berkembang pada zaman Nabi, kedua ajaran tersebut didinamiskan melalui ekspresi budaya. Dan bagi kalangan tradisionalis itu adalah sunnah karena mengamalkan ajaran Islam dalam keseharian.

\section{Barzanji dalam Domain Budaya Bid'ah}

Penyematan vonis bid'ah dalam tradisi barzanji maupun tradisi Nabi lainnya sebenarnya lebih dimaknai sebagai bentuk ekspresi perlawanan budaya yang dilakukan oleh kalangan yang mengaku sebagai Wahhabi maupun modernis, bertujuan untuk menghapus segala bentuk tradisi-tradisi yang tidak difaedahkan dan diamanatkan dalam al Quran dan Hadits sebagai bentuk penyimpangan. Perlawanan budaya yang dimaksudkan di sini bukanlah menyangkut kontestasi ideologi Sunni-Syiah yang selama ini berkembang dalam kajian teologis maupun halhal sejenis yang hasilnya terjadi saling tudingmenuding antara yang beriman dan yang kafir dan mana yang haq mana yang batil. Bid'ah sebelum masuk ke dalam ranah teologis, sejatinya adalah bentuk kontestasi dan eksistensi cara pandang budaya Wahhabi dan modernis untuk diakui oleh umat muslimin lainnya. Oleh karena itulah, perlawanan budaya yang dilakukan keduanya sebenarnya sangat kaku dan konservatif mengikuti secara normatif-leksikal sesuai apa yang tercantum dalam al Quran dan Hadits sehingga bentuk budaya yang berbeda dengan apa yang mereka definisikan adalah sesat dan menyimpang. Budaya Islam yang benar adalah sesuai dengan kedua rujukan utama umat muslim sedunia tersebut dan menanggap bahwa budaya Islam yang berkembang selama ini merupakan bentuk sinkretisme dengan budaya lainnya, tidak sesuai dengan ajaran murni Islam.

Namun demikian, tulisan dalam subbab ini bukan dimaksudkan untuk membela modernis melalui pendirian kemurnian Islam-nya. Aplikasi cultural studies sebagaimana yang digunakan dalam makalah ini bertujuan untuk menunjukkan dimensi kritisisme budaya yang dibangun oleh modernis melalui vonis bid'ah-nya bahwa produk budaya, agama, maupun dominasi dari entitas tertentu haruslah terpisah dan berdiri secara sendiri tanpa ada pengaruh dari hal yang lain. Artinya bahwa, vonis bid'ah yang dilancarkan 
oleh kalangan modernis sendiri sebenarnya merupakan upaya dan semangat pembebasan budaya terhadap barzanji sendiri dari pengaruh kalangan tradisionalis. Barzanji bukanlah produk budaya Islam dan simbol identitas dari kalangan tradisionalis, namun memaknai barzanji adalah produk sastra berupa lirik puisi dan prosa saja tanpa harus diikuti dengan ritus peribadatan yang mengikuti dalam setiap pembacaan barzanji sendiri (Safrudin, 2010). Harus diakui bahwa kritisisme budaya yang dilancarkan kalangan modernis dan Wahhabi melalui vonis bid'ah-nya mempunyai kecenderungan mengarah pada aspek teologis, namun sebisa mungkin kita harus melihatnya sebagai bentuk kritik sastra yang selama ini lazim dan biasa digunakan sastrawan dalam mengkritik karya sastra tertentu berdasarkan pemikiran yang menjadi dasar analisisnya.

Mari kita meletakkan vonis bid'ah ini dalam rangka sebagai kritik sastra dan bukan sebagai kritik teologis yang berujung debat kusir tiada henti. Adapun kritikisme budaya yang dibangun dalam paradigma bid'ah oleh para kalangan Islam modernis ini bersumber pada tiga hal yakni (1) berdasarkan pada pemikiran yang bersumber secara text books dari al Quran dan Hadits sehingga corak pemikiran kritisnya lebih konservatif dan kaku, (2) memusatkan kepada peneguhan ibadah dalam wilayah simbol agama dan ritual, sehingga produk budaya yang tidak termasuk dalam wilayah tersebut adalah bid'ah (3) kritikan cenderung monolog yakni dalam satu arah dan bukan dialogis yang dua arah. Adapun yang menjadi fokus dari kalangan modernis ini sebenarnya lebih mengkritisi narasi-narasi sastra barzanji yang sifatnya fiksi yang tak faktual rujukannya dalam al Quran dan Hadits dimana memiliki kecenderungan bermuatan hiperbola yang menyanjung secara berlebihan Muhammad SAW sebagai al Masih seperti Nabi Isa AS oleh kaum Nasrani (Supani, 2007: 7). Modernis sendiri sangat afirmatif terhadap kitab barzanji yang menampilkan secara riil narasi-narasi historis riwayat Nabi Muhammad SAW yang sahih menurut al Quran dan Hadits.

Berikut ini sebagian dari kritikan budaya oleh kalangan modernis dalam barzanji untuk memberikan demarkasi yang jelas mana yang merupakan ruang ibadah dan mana yang merupakan ekspresi budaya di luar peribadatan agama.

Contoh Lirik Barzanji yang dianggap bid'ah.

Hambamu yang miskin mengharapkan

"Karuniamu (wahai Rasul) yang sangat banyak"

Padamu aku telah berbaik sangka 
"Wahai pemberi kabar gembira dan Pemberi Peringatan"

Maka tolonglah Aku, selamatkan Aku

"Wahai Penyelamat dari Sa'iir (Neraka)"

Wahai penolongku dan tempat berlindungku

"Dalam perkara-perkara besar dan berat yang menimpaku"

$$
\text { (al Atsari, 2010: 1) }
$$

Sekali lagi, perlu ditegaskan bahwa dimensi bid'ah dalam mengkritisi barzanji menurut kacamata kalangan modernis adalah lirik yang sifatnya hiperbola, fiksi, dan metaforik yang tidak ada rujukannya dalam al Quran dan Hadits seperti dalam bait 3 untuk mengajak berbaik sangka kepada Nabi. Hal itu menurut kritikan budaya kalangan modernis, lirik tersebut keliru karena menurut hadits yang diriwayatkan oleh Imam Muslim menyebutkan bahwa

"Janganlah mati salah seorang dari kamu melainkan ia berbaik sangka kepada Allah 'Azza wa Jalla. (HR Imam Muslim).

Artinya bahwa lirik barzanji tersebut menyimpang karena bukan kepada Nabi, namun berbaik sangkalah kepada Allah. Selain itu pula dalam bait 4,5,6 disebutkan bahwa sang Nabi adalah penyelamat bagi seluruh umat manusia. Al Quran juga menyebutkan:

"Sesungguhnya aku sekali-kali tiada seorangpun dapat melindungiku dari (azab) Allah dan sekali-kali aku tidak akan memperoleh tempat berlindung selain daripada-Nya" (QS Al Jin: 20-22).

Kalangan modernis sendiri berupaya untuk merekonstruksi kembali makna barzanji sebagai karya sastra besar dan bukan karya ijtihad ulama yang belum shahih kebenarannya. Hal inilah yang kemudian menjadi alasan mengapa kalangan modernis dan wahhabi sendiri sangat bersemangat dalam memvonis bid'ah sebagai bentuk ekspresi kritik budaya mereka. Barzanji memang meriwayatkan Nabi Muhammad SAW dari sejak lahir, diangkat menjadi rasul, hingga wafat dan dimaknai sebagai biografi beliau agar riwayat perjuangannya selalu diamalkan oleh umat Islam sedunia. Maka, perspektif cultural studies dalam melihat konstruksi bid'ah sendiri tidaklah selalu berujung pada penegasian dan pelarangan terhadap entitas tertentu. Namun justru, bid'ah sebagai bentuk ekspresi kritikan sastra yang dilakukan oleh kalangan modernis merupakan bentuk rambu indikator tentang shahih tidaknya ajaran Qur'ran dan Hadits dalam penulisan karya sastra seperti halnya barzanji itu sendiri. Makna bid'ah dalam cultural studies tidaklah bepretensi untuk mereduksi atau bahkan menghilangkan ekspresi budaya dalam umat Islam, namun justru sebagai upaya memberikan koridor yang jelas tentang 
ajaran agama dalam sebuah produk budaya.

\section{Simpulan}

Hal yang dapat kita simpulkan dalam kajian ini adalah studi barzanji berikut perdebatan mengenai keabsahan tradisi mauludan yang selama ini berkembang dalam masyarakat muslim Indoensia, janganlah ditempatkan dalam perdebatan teologis yang berujung pada debat kusir yang tiada henti. Harus diakui bahwa barzanji sebagai salah satu bentuk dari tradisi mauludan memang berakar dari Syiah kultural. Namun jangan sampai karena ada pengaruh kultural Syiah dalam barzanji kemudian ditafsirkan sebagai entitas yang bid'ah dan menyimpang dari ajaran agama Islam. Mendudukan antara yang sunnah dan bid'ah dalam menilai sebuah produk budaya jangan di ruang kontestasi Sunni Syiah karena keduanya memiliki akar filsafat, teologis, dan sejarah yang berbeda pula. Dalam makalah ini, penulis telah mencoba memberikan dimensi lain seputar dikotomi sunnah dan bid'ah dalam kajian cultural studies dimana antara sunnah dan bid'ah tidaklah dianalisis dalam ruang hitam-putih yang justru menimbulkan pretense stereotif kepada salah satu mahzab keagamaan. Namun sunnah dan bid'ah sebagai dikotomi yang saling mengoreksi dan melengkapi satu sama lain. Memang, penafsiran baru atas dikotomi sunnah dan bid'ah dalam kerangka cultural studies ini masih jarang dipakai oleh sarjana ilmu sosial karena biasanya kajian tersebut lebih dikuasai oleh sarjana teologis dan tarbiyah yang mempunyai sumber referensi yang kuat karena memang itu sudah menjadi lokus studi mereka. Barzanji sebagai karya sastra merupakan analisis baru dalam kajian budaya yang tentunya masih harus mengkorelasikan referensi dengan ilmu teologis dan tarbiyah. Dalam hal ini, penulis telah mencoba membawa barzanji tersebut dalam ruang diskursus yang baru dengan menempatkan kritik sastra bersumber teologis tersebut. Penulis sadar bahwa kajian ini masih banyak kekurangannya karena analisis ini masih baru dan belum banyak dipakai oleh kalangan akademisi lainnya. Penulis menantikan saran dan kritikan terhadap karya sejenis di masa depan.

\section{Daftar Pustaka}

Al Atsari, Abu Salma. 2010. Studi Kritis Syair-syair Barzanji dan Burdah. Al Hujjah Risalah. Volume 4, Nomor 50: 1-2.

Albiruny. 2012. Sejarah al Barzanji. http://biruny.blogspot.com. [27 Juni 2012]. 
Hall, Stuart. 2006. Cultural Studies: An Introduction. London: Routledge.

Junnaid,M. 2008. Tradisi Barzanji Sya'ban Masyarakat Bugis Wajo di Pantai Tanjung Jabung Timur. Kontekstualita. Volume 23, Nomor 1: 80-92.

Mawardi, Kholid. 2009. Shalawatan: Pembelajaran Akhlak Kalangan Tradisionalis. Insania. Volume 14, Nomor 3: 500-511.

Munawaroh, Siti. 2007. Tradisi Pembacaan Barzanji bagi Umat Islam. Jantra. Volume 2, Nomor 3: 34-40.

Muzakka, Moh. 2003. Tradisi Lisan Pesantren dan Pemberdayaan Politik Santri. Makalah disajikan pada Seminar Internasional Tradisi Lisan Nusantara IV dan Festival Semarang Pesisir. Semarang. Tanggal 2-5 Oktober 2003.

Najieh, Abu Ahmad. 1987. Terjemah Maulid al Barzanji. Surabaya: Mutiara Ilmu.

Nizaruddin, Ahmad. 2007. Tradisi Peringatan Maulid Nabi. Kediri: Maktab Dakwah Dan Bimbingan Jaliyat Rabwah.

Paisun. 2010. Dinamika Islam Kultural. Makalah disajikan pada Annual Conference on Islamic Studies (ACIS) Ke-10. Banjarmasin. Tanggal 1-4 November 2010.

Safrudin. 2010. Peringatan Maulud Nabi dan Teks al Barzanji. http://rere-comp. blogspot.com. [7 November 2012].

Sholikhin, Muhammad. 2011. Ritual Eु Tradisi Islam Jawa. Yogyakarta: Penerbit Narasi.

Supani. 2007. Tradisi Maulud: Pro dan Kontra. Ibda. Volume 5, Nomor 1: 72-89.

Suparjo. 2008. Islam dan Budaya: Strategi Kultural Walisongo dalam Membangun Masyarakat Muslim Indonesia. Komunika. Volume 2, Nomor 2: 178-193.

Syadzili, Ahmad Fawaid. 2010. Ensiklopedi al Quran. Jakarta: PT. Kharisma Ilmu.

Ta'rifin, Ahmad. 2010. Tafsir Budaya atas Tradisi Barzanji dan Manakib. Jurnal Penelitian. Volume 7. Nomor 2: 1-14. 